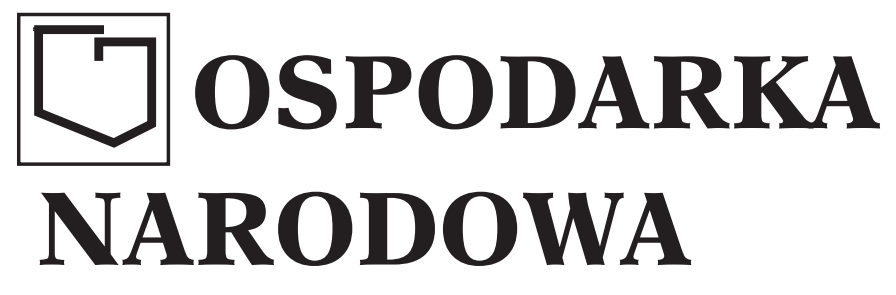

Rok XIX styczeń-luty

2008

John BRADLEY*

\title{
National and Regional Development Policy: Comparing Ireland and Poland ${ }^{1}$
}

It would be going too far to think of Ireland as if it were purely a regional economy, its growth driven by its export base. The kinds of macroeconomic issues that matter for bigger national economies also matter for Ireland. But by moving back and forth between thinking of Ireland as a productivity-driven national economy and as an export-driven regional economy we may be able to get a fuller picture.

Krugman, 1997

\section{National and regional economies}

At the present interesting stage of Polish economic development, it is useful to examine both Ireland and the 16 Polish regions (or voivodships) as European archetypes of small regional and national economies, and to reflect on the implications that this has for the design and evolution of successful growth strategies. Within the European single market and the euro zone, the economies of small nation states and regions have more in common than is often recognized.

Ireland is a small, open economy with a tiny share of world trade and little or no market power. With a population today of about 4 million, it ranks below Poland's Mazovia (5.1 million) and Silesia (4.7 million) regions. In 1960, when its population had fallen to a low point of 2.8 million, Ireland would

\footnotetext{
* The author, formerly a professor at the Economic and Social Research Institute (ESRI) in Dublin, Ireland, runs research consultancy Economic Modelling and Development Strategies (EMDS).

1 Paper submitted in November 2007.
} 
only be sixth in rank size compared to present Polish regions. But even within such a small economy, there is a significant degree of heterogeneity in Ireland between the more urbanized and developed East/South and the more rural, less developed West/North. Hence Ireland has characteristics of a national economy (albeit, a very small one) as well as divergent internal regional economies. As a possible role model in the design of the special development program for the eastern Polish regions, the example of Ireland is relevant. Much thought on the development of Polish regions, in terms of national and regional policy paradigms, will be necessary if Polish regional administrations are to achieve the best return from capturing gains from European Union and national policies as well as building on their own, rather limited, locally devolved powers.

A useful perspective for examining Irish regional development policy is that of a very small state that, nevertheless, has some internal socioeconomic regional disparities that may present barriers to wider national development and spatial equity goals. Consequently, Irish policymakers, when they initially developed their national policies, were probably closer in their thinking to present-day Polish regional policymakers than they were to, say, Spanish, British, German or French national government policymakers. A strategy of specialization in a very limited range of productive activities is more necessary in a small economy (Ireland) than in a large one (Poland). At the Polish regional level, focus and specialization will also be of paramount importance.

The role of public administrations (national and regional) as "strategic organizers" in a global economy dominated by market forces is very different from the previous role of communist "central planners" or of postwar Western Keynesian demand management "fine tuners." Today, public administrations exercise their role in a complex collaboration with private businesses and other social partners, and not as a substitute for the market economy. Irish governments had to learn to think strategically, since there was nobody else to carry out the task for them. No amount of EU funding would have compensated for the absence of a high level of strategic thinking by Irish policymakers. Nor will the mere availability of EU funding automatically produce dynamic growth within the Polish regions.

Of course the Polish regional situation is somewhat more complicated than the Irish case because of a division of economic policy planning responsibilities between Warsaw and regional capitals. The recent decision to allocate about one third of total Polish EU Structural Fund assistance for 2007-2013 to 16 separate Regional Operational Programs (ROPs) plus a special Eastern Poland OP has simply brought these issues out into the open. The targeting of special assistance on the five poorest regions of eastern Poland is a recognition that these regions are likely to fall further behind the performance of the more prosperous western regions unless their specific barriers to growth are identified and addressed ${ }^{2}$.

2 Designing Polish regional strategies is made even more difficult by the relatively poor quality of available regional economic data. A first attempt to construct complete Polish regional accounts from officially published partial data is described in Bradley et al., 2006. 


\section{National development policy in a small, open economy}

From the late 1980s (at the start-up of the EU development programs) and during the 1990s (for a second program), the situation in Ireland differed from that of the other three so-called "cohesion" countries (Greece, Portugal and Spain), in a key aspect. Irish economic policymakers did not formally "regionalize" their development strategies. It was not until the third National Development Program (NDP 2000-2006) that a formal division of the country into two separate regions was first undertaken.

Because of the small size of the Irish economy and the centralized nature of its public administration, internal regional development is already addressed to a very large degree by the policy decisions taken at the national level. For example, "national" or "sectoral" Operational Programs (OPs) of the first two EU-assisted National Development Plans (NDPs) that were implemented between 1989 and 1999 had no significant regional input. Only during NDP 2000-2006 was a modest effort made to put in place regional planning organizations.

For NDP 2000-2006, two Regional Operational Programs (ROPs) were designed, alongside the dominant national or "sectoral" Operational Programs. The effect was to designate the poorer of the two regions (so-called Border, Midland, West, or BWM) as Objective 1 while the more developed region (socalled Southern and Eastern, or S\&E, focused on Dublin) was eligible only for a lower rate of transitional aid. The nature of the division was partially based on economic criteria but also on pragmatic political grounds. A key recommendation of a preliminary investigation of investment priorities [Fitz Gerald et al., 1999] was the urgent need for a strategic spatial planning framework, since investment needs are not independent of the spatial pattern of development, and public investment in itself is a crucially important regional policy tool. Following a process of consultation and research, which started in 2000, the government published the National Spatial Strategy 2002-2020 (NSS) in 2002, which was both a statement of government policy intentions and a blueprint for the spatial aspects of development in Ireland. Just as Poland's internal regional disparities tend to lie on an East-West axis, so do Ireland's. In the case of Poland, it is the eastern regions that suffer from peripherality and underdevelopment, that have their origins deep in Polish history. In the case of Ireland, it is its western region that suffers from underdevelopment, and it also has explanations that are a mixture of history and economic geography.

Irish internal regional problems are addressed to a very large degree by the "national" or "sectoral" OPs of NDP 2000-2006, which are now funded mainly out of national financial sources. However, the special problems of the poorer western and northern Irish region (which retained Objective 1 status), that were addressed by a specific ROP, should probably be considered as "second order" policy targets, more akin to the internal problems of a specific Polish region than to the inter-regional problems of Polish national cohesion. Devolving policy too much to the regional level in Ireland would run the risk of making national policy incoherent and confused. On the other hand, retaining a top- 
down policy stance at the national level in Poland would almost certainly run the risk of making regional outcomes inefficient and ineffective.

The strategic orientation of Irish national economic policymaking over the past four decades has, with few exceptions, always emphasized the need to face the consequences of the extreme openness of the economy, to encourage export orientation towards fast growing markets and products, and to align the economy with all major European initiatives ${ }^{3}$. Four broad domestic policy strategies accompanied the external reorientation of the economy. Of primary importance was the pursuit of policies designed to bring about a steady buildup of the quality and quantity of education and training of the work force. Looked at in terms of Ireland as an economic sub-region of the British Isles, the low level of human capital, combined with an almost total absence of modern industrial experience, was regarded as the main barrier to growth ${ }^{4}$. Next in importance was the need for major improvements in the quality of the economy's physical infrastructure, although early freedom of action here was severely constrained by lack of finance. The next barrier to development was a pervasive lack of competitiveness, and called for the facilitation of the growth of a competitive Irish business sector through improved management, quality marketing, better services, lower costs of utilities, and more systematic linkages with other complementary activities (or clustering). Finally, as it emerged from behind protective tariff barriers in the early 1960s, there was a need for a more stable domestic macroeconomic policy environment, where "stop-go" budgetary changes did not disrupt long-term public sector and business planning.

Although these policy strategies were pursued, in one form or the other, since the late 1950s, the pace of policy design and implementation accelerated after 1989, with the advent of EU development aid and multi-year investment planning. EU-aided NDPs in Ireland permitted greater focus and intensification of previous policy efforts, rather than requiring a completely new approach to economic development. In the Polish regional case, appropriate institutions and policies had to be constructed almost from a zero base, and the current 2007-2013 programming period is likely to witness a diversity of policy initiatives as regions stake out their own areas of policy competence.

\section{Is there a need for regional policy?}

When one examines how economies have developed over time and over space, three characteristic features stand out:

3 Barry (ed.), [1999], provides a comprehensive overview of recent Irish economic development.

4 It should be noted that Ireland was formally incorporated into the United Kingdom (of Great Britain and Ireland) in 1800, and only acquired its political independence in 1922. Economic independence (or autonomy) took another 40 years to achieve, since the Irish economy remained completely integrated with that of the UK. For example, until the 1960s over 90 percent of Irish exports went to the UK, and sterling notes circulated in Ireland alongside Irish banknotes, with a legally binding parity. 
i. Economic activity tends not to be spread uniformly over space or over sectors, but tends to cluster or concentrate;

ii. Such clustering is clear evidence of some kind of increasing returns (i.e., doubling inputs more than doubles outputs) and this should be exploited by policymakers;

iii. Growth centers in specific locations (usually cities of above a certain size) will tend to interact with each other over space to form corridors, or elongated growth centers.

As a description of the dynamics of growth, the above points have wide application. The first element simply describes the physical realities of the cities, towns, villages and less populated hinterlands to be found in any country or region. The second element provides an economic explanation for why clustering occurs, and has been a very active area of research in industrial economics over the past decade (i.e., the "new" growth, trade and spatial economic theories) $)^{5}$. The third element is a logical consequence of the first two and merely describes the interaction of two or more contiguous growth poles as their areas of influence begin to overlap.

The early (pre-1960) approach to regional industrial policy in Ireland was unsuccessful since the normal processes of clustering and regional concentration were impeded both by the imposition of high tariff barriers and by a public policy of forced geographical dispersal of locally-owned, import-substituting firms. The only example of a self-sustaining "industrial district" on the island of Ireland - the shipbuilding and textiles agglomerations centered on Belfast during the period from the mid $19^{\text {th }}$ century to the early decades of the $20^{\text {th }}$ century - declined rapidly after World War $\mathrm{II}^{6}$. The promotion of regional dispersal in pursuit of spatial equity goals was almost certainly at some expense to strict economic efficiency criteria.

The post-1960 industrial strategy in Ireland took place in an era of free trade and can be characterized as a process whereby the State Industrial Development Agency (IDA), using a wide range of incentives, bid for subcontracting roles from global multinational firms and then attempts to influence the allocation of these activities over the Irish regions in order to satisfy conflicting mixtures of economic, social and political criteria. The success of inward investment to Ireland illustrates how rapid changes that are taking place in the international marketplace, many of which have served to return the focus of attention to economic regions as natural units of production [Sabel, 1989]. Discussions of industrial policy began to take account of how the environment within which firms operate had been changing rapidly, with important consequences for the growth of successful clusters of modern innovative firms [Porter, 1990], [Best, 1990 and 2001].

5 Fujita et al. [1999] is the standard technical work on the new spatial economic theories. Warsh [2006] is a readable account of the role of human capital. Best [2001] provides an excellent introduction into modern economic approaches to industrial strategy design.

6 Northern Ireland, whose capital was Belfast, remained part of the United Kingdom after 1922. 
During most of the industrial revolution the geographical "region" was a natural unit of economic activity and analysis. The nation's economy was simply the sum of its parts, and national economic development was only marginally controlled by central political authorities. For example, the growth of Belfast on the island of Ireland during the second half of the 19th century was a good example of such a semiautonomous process [Bardon, 1982]. However, by the 1960s regions had become much less important as a focus of economic activity. According to Charles Sabel, the demise of the old regional economies came about because:

A system of mass production incorporated as subcontractors the pieces of the older regional economies which it had not already swept aside [Sabel, 1989].

Sabel lists the crucial developments as follows [Sabel, 1989]:

i. The emergence of conspicuously successful geographical regions, such as Silicon Valley and Route 128 in the United States, the "Third" Italy, the "Second" Denmark, Baden-Württemberg, etc.; Ireland (or at least some of its more urbanized regions) might be considered as a late entrant to this desirable club;

ii. The dramatic reorganization of large multinational firms into many operating units with enhanced local autonomy;

iii. The convergence of large- and small-firm structures: the former splitting up into specialized units; the latter grouping around centralized facilities (laboratories, marketing agencies, etc.);

iv. The transformation of local governments from welfare dispensaries to jobcreation agencies;

v. The cooperation of trade unions in the industrial reorganization at the plant or regional levels.

These changes have created a new form of local development that parallels emerging corporate patterns of behavior [Sabel, 1989]. Like firms, small regions know that they must survive in a turbulent economic environment. Like firms, they must accommodate volatility through flexibility. For regions, flexibility requires facilitating the re-combination of resources among companies, so that the latter may re-deploy them internally. And as with firms, many regions renovate themselves only with the greatest difficulty.

High scores on empirical measures of international competitiveness are central to the attractiveness of economies like Ireland. Such measures range from wage costs, output prices, profitability rates, etc., to wider measures related to product innovation, design, quality and reliability ${ }^{7}$. Public policy can be invoked to influence an otherwise poor competitiveness position. The preferred approach in recent decades is through subsidies to labor, capital, energy, etc., combined with lower rates of corporate taxation, improved physical infrastructure and raised levels of human capital. State intervention in Ireland

7 The analysis and monitoring of competitiveness is now a major and essential element of public policymaking in Ireland, in particular by the National Competitiveness Council. 
has been directed with vigor to address and enhance an otherwise averageto-mediocre level of international cost competitiveness, mainly through low corporate taxation, but also with a range of subsidies. Only in the late 1980s were strategic frameworks developed within which the above sources of national competitive advantage could be placed (the so-called Porter diamond - [Porter, 1990], [Best, 1990 and 2001]). Ironically, Irish strategies had already been evolving along these lines since the early 1960s, even if all the implications were not fully understood.

\section{The Irish growth and development process}

During the 18-year period of the previous three EU-assisted NDPs, the Irish economic policymaking environment can be characterized as having shifted from one appropriate to a state on the periphery of Europe to that of a region more fully integrated into an encompassing European economy. In Ireland, monetary policy and aspects of fiscal autonomy have been progressively ceded to Frankfurt and Brussels. The willingness to go down this road was perhaps conditioned as much by the domestic policy failures of the late 1970s and the early 1980s that were made in the area of demand management, as by the innovations in EU regional policy and Structural Fund aid. Nobody in Ireland believes any longer that impacts emanating from policies of discretionary demand management, "fine tuning", or subsidies to failing enterprises, provide a useful context for development success for a small economy in the long run. Nor does anyone believe that fiscal or monetary policy would be sufficient to shield the Irish - or any other small open economy or region - from a global recession.

Perhaps the key similarities between Ireland and the Polish regions are that Irish policymakers have downplayed those areas of national economic management which they believe are best handled within larger blocks, like the $\mathrm{EU}$, and emphasized those remaining policies that address the specific local efficiency of the supply side of the economy (education, training, competitiveness, R\&D, etc.), as well as issues related to equity (Social Partnership). Such policies will always retain essentially local characteristics. The Polish regions have never had much fiscal autonomy and have no monetary autonomy, but they are in a position to select development instruments from a range similar to Irish policymakers.

\section{Key success factors in Ireland}

We summarize briefly a logical sequence of six interconnected effects that brought about that impressive Irish convergence result, and then ask if there is any similarity between this sequence of events and the development scenarios for eastern Poland.

First, the Irish economy in the late 1970s and for the first half of the 1980s was seriously and massively destabilized, with high unemployment, relatively high inflation, and public finances almost out of control. But the root causes 
- i.e. the OPEC II global recession and the aftermath of the fiscal profligacy of 1977-82 - had vanished by the late 1980s, and the international economy was strengthening.

Second, there were the effects of the Structural Funds, from the late 1980s onwards. These had both demand and supply effects. As you actually build a road, it injects income and expenditure into your economy. But the longlasting benefits of building a road come when it is available to connect your cities and to transport goods more efficiently into and out of your economy. So, the beneficial effects of Structural Funds were initially experienced as a construction boom, and gradually fed into enhanced supply-side performance as major infrastructural projects were completed.

The third event was the beneficial effect of Ireland joining the European Monetary System (or EMS) that was instituted in 1979 and served as a precursor of the Economic and Monetary Union (or EMU). But the credibility benefits of Ireland's membership of the EMS were delayed by about a decade. The convergence of Irish interest rates to the lower German (and later, euro) rates served to stimulate investment (particularly house building) as well as consumption.

The fourth event was the massive increase in the inflow of mainly U.S. foreign direct investment (FDI), most of it in high technology areas (Barry and Bradley, 1997). The characteristics of the global technology boom of the years of the Clinton presidency are well known, and Ireland was uniquely positioned to reap the benefits in terms of a massive increase in mainly U.S. FDI. This was in part a spin-off benefit of the Structural Funds, making use of the improved infrastructure and human capital. It was also due in part to Ireland's access to EU markets for exports produced by multinational companies located and producing in Ireland. Additionally, of course, one of the long-term elements of Irish policy since the late 1950s was a low rate of corporate taxation, designed to attract inward investment.

The fifth event concerned the fiscal stabilization of the 1987-89 period, where Ireland experienced the nearest equivalent of the type of policy regime switch that fueled the Polish liberalization of post-1989. Public consumption was slashed; improved monitoring and evaluation of public investment was instituted, driven by the EU requirements for Structural Fund aid. By strongly signaling its firm intention to join the EMU, even in the absence of its largest trading partner, the United Kingdom, the benefits of fiscal stabilization were reinforced.

Finally, in Ireland there was an evolving social partnership (involving employers' organizations, trade unions and the government) that eased the distribution conflicts and disputes that come with recovery and rapid growth. National wage bargaining for a rolling series of three-year periods were negotiated at rates that preserved the cost competitiveness of the more vulnerable indigenous firms, and which eventually were used as a way of lowering the high tax rates that had been inherited from the early 1980s. 


\section{Underlying mechanisms of success}

In a recent essay on Ireland's growth, Paul Krugman suggested that economies like Ireland can be viewed in two different ways: as a national economy or as a regional economy (Krugman, 1997). The facts that one is examining may be the same, but the national or regional perspectives will make a big difference to what one believes is important. Being a region involves more than small size and dependence on trade. Krugman suggests that what makes Ireland like, say, Massachusetts, is that its labor market as well as its product and capital markets are very open. Here, it is in sharp contrast to many other small EU and CEE states.

It is when he turns to examining the self-reinforcing nature of Irish success that Krugman comes close to the issues that will be central to the management of all small open EU economies (states and regions) in the next decade. Krugman suggests that the Irish experience is a working out of Marshallian externalities, i.e.:

(a) An initial clustering of similar industries (mainly foreign owned and in the areas of computer equipment and pharmaceuticals) supported by local suppliers of specialized inputs subject to economies of scale.

(b) These clusters generated a local labor market for skilled workers which further facilitated the growth of the cluster. The human resource policies of the EU Structural Funds were crucial at this stage.

(c) Spillovers of information further encouraged growth in the electronics and pharmaceutical sectors and provided the basis for additional clustering effects, often in traditional areas that benefited from new technologies (e.g., food processing). To facilitate this stage, the improvements in physical infrastructure and in the productive environment supported by the EU were crucial.

(d) A consensual process of social partnership was put in place from 1996 onwards to ensure that there were as few losers as possible in the economic restructuring that accompanied such a virtuous circle, with the result that growth was less likely to be choked off by industrial unrest as the social partners negotiated over their respective shares of added value. Although there were valuable lessons to be learned from wider EU experience in this area, the policies actually put in place were domestic in origin.

However, Krugman [1997] draws attention to some of the risks to which a country or region like Ireland is exposed. First, the dynamic foreign manufacturing base is concentrated on a narrow range of technologies that are fast moving towards maturity. Second, the policy initiatives that ensured an advantageous "first mover" status in the early 1960s may not be sufficient to facilitate the inevitable switches to newer technologies since other countries and regions have been learning by watching Ireland doing.

The Irish dependence of inward investment (FDI) has other downsides. The direct benefit to the Irish economy consists mainly of the wages paid to Irish workers employed, the national product and employment generated indirectly 
in the indigenous manufacturing and market services sectors, and the relatively modest yield in corporate profits tax (given the low 12.5\% rate now in force). From this must be netted off the costs of attracting these firms to Ireland (investment and training grants and subsidies, and other promotional activities). However, the foreign sector tends to be fairly capital- and R\&D-intensive, sources most of its inputs abroad, and repatriates the major part of its profits. Since the wage bill paid by the foreign sector is the major benefit, attempting to raise competitiveness by lowering wage rates reduces that benefit. This suggests that a policy based on a narrow form of cost competitiveness (focused purely on low wages) is inappropriate in Ireland. Rather, firms requiring high skills, and able to pay for these skills while remaining highly profitable, need to be targeted.

Progressive trade liberalization within Europe was always likely to entail substantial industrial disruption in the periphery, either defined as the member states on the western and southern edge of the EU or as those sub-regions of member states that were located far from the centers of population and economic activity. What Krugman noted with respect to the southern periphery's accession to the EU in the 1980s applies with equal force to the new member states, and the Polish regions in particular:

The trade expansion produced by EU enlargement is simply not likely to be as painless as the trade expansion produced by the formation of the Community and earlier enlargement. There will certainly be income distribution problems created by the changes, and also quite possibly some real costs in terms of unemployment [Krugman, 1987].

One of the potential difficulties that the periphery faced in adjusting to EU membership was the possibility that as trade barriers fell, industries that have a high share of the manufacturing sectors exhibiting increasing returns to scale (IRS) would be attracted away from the periphery towards the core because of economies of agglomeration. This process resulted in the decline of old Irish indigenous industries in IRS sectors. However, the influx of multinational companies in precisely these sectors more than dominated this decline, so the share of Irish employment in IRS sectors has increased substantially ${ }^{8}$.

The experience of Greece, however, is a cautionary tale that the Polish regions should heed. It showed that trade liberalization, while necessary, is not a sufficient condition for large-scale FDI inflows. The share of manufacturing FDI relative to GDP in Greece remained low, and stagnant, over the whole period of the NDPs. The various factors identified in the Irish case, particularly macroeconomic stability, the presence of a streamlined bureaucracy and rapidly improving stocks of infrastructural and human capital, do not appear to have

8 It is useful to make a distinction between IRS at the plant level and at the industry level. The foreign firms locating in Ireland have tended to be in sectors where there are IRS at the industry level (computer equipment, pharmaceuticals, instrument engineering) but CRS at the plant level. 
been in place in the Greek economy, substantially reducing its attractiveness as a platform for multinational investment [ESRI, 1997].

Most of the FDI into Irish manufacturing entails the construction of entirely new state-of-the-art factories on greenfield sites. In this it differs substantially from the modernization of existing plants on "brownfield" sites that characterizes much of the FDI inflows into Central and Eastern Europe in recent years. Most of this investment is oriented either towards the home market (which is large in the case of Poland), or, at best, towards geographically-proximate markets (where the western Polish regions have considerable advantages over the eastern regions.

FDI inflows into Ireland did not go primarily into the more traditional sectors in which the economy of the 1960s and 1970s had a comparative advantage. In fact, traditional measures of revealed comparative advantage were a very poor predictor of subsequent sectoral developments. There are two reasons for this: firstly, a number of manufacturing sectors have significant non-tradable elements, and developments in these sectors would not therefore depend on comparative advantage; secondly, the substantial FDI inflows that occurred also turned out not to depend on comparative advantage. In terms of the 10 sectors for which the 1960s data are available, sectors into which FDI flows were substantial but in which Ireland had no revealed comparative disadvantage were chemicals and metals and engineering [Barry and Hannan, 1996].

If comparative advantage then had little influence on the sectors into which export-oriented FDI flowed, how do we explain the sectoral destinations of such inflows? It appears from the Irish experience that FDI manufacturing inflows go primarily into sectors in which there are increasing-returns-to-scale at the level of the firm rather than the individual plant. O'Malley [1995] identified a group of NACE-coded manufacturing sectors as characterized by increasing returns of this type ${ }^{9}$. He shows that approximately $63 \%$ of foreign-industry employment in Irish manufacturing is located in these sectors, compared to $23 \%$ of indigenous manufacturing employment. The proportion of foreign-industry employment in these sectors is in turn close to the proportions prevailing in the core EU economies.

This suggests that foreign firms have a competitive advantage in IRS sectors. The reasons why this might be so are not hard to identify. There are strong advantages to incumbency in IRS sectors, in terms both of low unit costs of production due to having already attained scale economies, and in terms of having established distribution networks. Since the move to multinational operations takes place some significant period of time after the start-up of a firm, multinationals will have already attained some of these benefits of incumbency.

9 O'Malley's classification of the increasing returns sectors is also used by Barry [1996]. Ireland does not appear to attract FDI into sectors in which there are strong IRS at the plant level (e.g., in the automobile industry), arguably because of the small size of the country. 


\section{Lessons for the Polish regions}

The new EU member states from Central and Eastern Europe, as well as their regions, have considerable cost advantages, improving human capital and physical infrastructure, geographical proximity to the core markets of Europe, and stabilizing macroeconomic, fiscal and monetary environments. In other words, they resemble Ireland of the late 1980s. The future for Ireland is more likely to involve both a shift towards greater complexity (new products, emerging technologies) as well as a more active relationship with the rapidly modernizing indigenous sector. Indeed, the product cycle model fits the stylized Irish facts rather well: early inward investment in simple standardized products ("screwdriver" operations), subsequent shifts to maturing products (e.g., Intel chips) and a potential for attracting more R\&D-based activity in the area of new products.

In exploring the policy environment of the Polish regions, there are some inescapable facts of life that need to be faced. First, within the Polish fiscal union, there is generally a level policy playing field. Of course, this does not always operate to the benefit of, say, the poorer eastern regions. Having to apply Polish corporate tax rates means that the eastern regions are at a disadvantage relative to some neighboring states with lower corporate tax rates, and even relative to Ireland. The fact that Poland remains outside of the euro zone for the time being means that the strong zloty places Polish firms at some degree of competitive disadvantage in the wider European marketplace. On the other hand, the fact that the Polish regions do not have to finance their regional public sector deficits out of their own tax resources, and the poorer ones benefit from large financial transfers from Warsaw, permits them to engage in a deeper and wider range of public expenditure programs. One such policy, the provision of a high rate of subsidy to private firms, has shortterm benefits in terms of attracting inward investment and safeguarding jobs, but almost certainly operates against the rise of a regional growth dynamic in the longer run. The danger is that a grant-seeking culture will drive out risk-seeking entrepreneurship.

Best [1990] has examined the phenomenal success of the northern Italian regions, centered on Emilia-Romagna, in contrast to the very poor performance of the southern region of the Mezzogiorno ${ }^{10}$. What this illustrates is that one is unlikely to be able to explain away interregional differences in economic performance simply in terms of differences in fiscal, monetary, or other conventional state-wide policies. History plays a role, as does geography, and conventional policy can act as a compensating mechanism. But it requires

10 The Mezzogiorno region of southern Italy has given its name to a phenomenon of underdevelopment and dependency that arose originally when the much richer northern Italian regions gave generous long-term income transfers to the south, which had an unintended side effect of locking the south into a low-efficiency, low-productivity, low-entrepreneurial dependency. 
a detailed strategic framework to get to the root causes of regional success and to suggest systematic remedies for failure.

Best suggests that regional development is most successful where two conditions hold:

i. A sufficient degree of policy autonomy is available that permits freedom of action to address local problems;

ii. Economic and business policies are designed and implemented in tandem: the first to design an attractive environment in which business can flourish; the second to recognize and exploit profitable opportunities where they exist, and to feed back information to policymakers where problems and obstacles are identified.

This process is difficult to "operationalize" if there is an inadequate stock of research-based knowledge or a failure to draw comprehensively from the available pool of research. Sovereign states, guided by good research, can use economic policies to influence the environment within which businesses can function efficiently, even though their freedom of action has diminished as fiscal and monetary power is ceded to supranational organizations such as the European Union. Polish regions have much less policy autonomy and must take almost all key aspects of the economic policy environment as set externally to them by the Polish state of which they are part. But regions are not completely powerless when it comes to policymaking, and can sometimes use industrial policies to influence conditions in their favor relative to the other regions of their nation state. Nevertheless, policymakers in regions would be well advised to attempt to understand how national economic policies affect them differentially. The tendency in poor regions has been to call for some form of "compensation" to offset actual or perceived disadvantages within the nation state. Unfortunately, such "compensation" often comes in the form of financial transfers from the core regions to the periphery regions that can blunt regional competitiveness, prevent change, and engender dependency.

The challenge facing regional policymakers is to understand how national policies can have both positive and negative regionally asymmetric impacts, while acknowledging the extremely constrained scope for designing offsetting region-specific policies within the context of the nation state. One possible reaction is for regional policymaking to become inward-looking and to focus on intraregional distributional issues. A much healthier reaction is for regions to become more outward looking and to engage with the more complex, political and fluid rules of the global marketplace as they seek to optimize gains from local policy initiatives.

At the risk of oversimplification of what are very complex issues, what an examination of the recent performance in Ireland shows is that the intelligent combination of economic policy and business strategy can generate huge synergies in terms of rapid national growth and convergence. To achieve these synergies requires a degree of economic policy autonomy that can be used, for example, to protect workers who lose their jobs in declining sectors and who require extensive retraining for other occupations. But, more importantly, 
policy autonomy needs to be directed at addressing weaknesses shown up by industrial strategy frameworks such as the Porter diamond [Porter, 1990] and the Best capability triad [2001].

In his reflection on the Irish growth experience, U.S. economist Paul Krugman stressed the need for a better balance between a purely regional paradigm, with growth driven by an export base, and the kinds of macroeconomic and productivity-driven issues that matter for national economies, even small ones. Ireland has adjusted to thinking about its economy in national as well as regional frameworks. The Polish regions, as they design their EU-assisted Regional Operational Programs, have just embarked on that exercise. Regional policy within large EU member states such as Poland has a tendency to be "palliative," in the sense that it attempts to make the regional disparities easier to endure rather than making any serious attempt to eliminate them. The main policy instrument used is often income support transfers from richer to poorer regions, a process that does not exist to anything like the same extent between richer and poorer countries of the EU. It appears to be politically difficult to design regional policies that introduce fundamental differences between regions of a nation state other than in terms of the level of income redistribution. But if the Polish regional economies are to be renewed, big innovations are precisely what are needed.

\section{Bibliography}

Bardon J., [1982], Belfast: An Illustrated History, Belfast: The Blackstaff Press (reprinted with corrections in 1995).

Barry F., [1996], Peripherality in Economic Geography and Modern Growth Theory: Evidence from Ireland's Adjustment to Free Trade, World Economy, Vol. 19, No. 3, pp. 345-65.

Barry F. (ed.), [1999], Understanding Irish Growth, London, Macmillan.

Barry F., Bradley J., [1997], FDI and Trade: The Irish Host-Country Experience, „Economic Journal”, 107 (445), pp. 1798-1811.

Barry F., Hannan A., [1996], On Comparative and Absolute Advantage: FDI and the Sectoral and Spatial Effects of Market Integration, Center for Economic Research Working Paper WP96/19, University College Dublin.

Best M., [1990], The New Competition: Institutions of Industrial Restructuring, Cambridge: The Polity Press.

Best M., [2001], The New Competitive Advantage: The Renewal of American Industry, Oxford: Oxford University Press.

Bradley J., Zaleski J., Tomaszewski P., Zembaty M., Wojtasiak A., [2006], Ocena wptywu Narodowych Strategicznych Ram Odniesienia i wybranych Programów Operacyjnych na lata 2007-2013 na gospodarki polskich województw przy pomocy modeli regionalnych HERMIN, collective report, Wrocławska Agencja Rozwoju Regionalnego SA., Wrocław.

ESRI, [1997], Single Market Review 1996: Aggregate and Regional Aspects: The Cases of Greece, Ireland, Portugal and Spain, London, Kogan Page, in association with the Office for Official Publications of the European Communities, Luxembourg.

Fujita M., Krugman P., Venables A., [1999], The Spatial Economy: Cities, Regions, and International Trade, The MIT Press, Cambridge. 
Krugman P., [1987], Economic Integration in Europe: Some Conceptual Issues, [in:] Efficiency, Stability and Equity, (ed.) T. Padoa-Schioppa, Oxford, Oxford University Press.

Krugman P., [1997], Good News from Ireland: A Geographical Perspective, [in:] International Perspectives on the Irish Economy, (ed.) A. Gray, Dublin, Indecon Economic Consultants.

O'Malley E., [1995], Industrial Structure and Economies of Scale in the Context of 1992, [in:] The Role of the Structural Funds: Analysis of Consequences for Ireland in the Context of 1992, Policy Research Series Paper No. 13, Dublin, The Economic and Social Research Institute, pp. 203-49.

Porter M., [1990], The Competitive Advantage of Nations, London, Macmillan.

Sabel C., [1989], Flexible Specialization and the Re-emergence of Regional Economies, [in:] Reversing Industrial Decline, (eds.) P. Hirst and J. Zeitlin, Oxford, Berg Publishers.

Warsh D., [2006], Knowledge and the Wealth of Nations: A Story of Economic Discovery, New York, W.W. Norton \& Company.

\title{
NATIONAL AND REGIONAL DEVELOPMENT POLICY: COMPARING IRELAND AND POLAND
}

\author{
Sum mary
}

The paper describes how, within the European single market, the economies of small nation states and regions of larger states have more in common than is often recognized.

The author suggests that, as a role model in the design of a special development program for the eastern Polish regions, the example of Ireland is relevant to Polish regional administrations as they attempt to achieve the best return from capturing gains from European Union and national policies as well as building on their own, rather limited, locally devolved powers.

The analysis demonstrates that during the 18-year period of three EU-assisted investment programs, the Irish economic policymaking environment shifted from one appropriate to a state on the periphery of Europe to that of a region more fully integrated into an encompassing European economy. The author concludes that the challenge facing regional policymakers is to understand how national policies can have both positive and negative regionally asymmetric impacts, while acknowledging the extremely constrained scope for designing offsetting region-specific policies within the context of the nation state. It is politically difficult to design regional policies that introduce fundamental differences between regions of a nation state other than in terms of the level of income redistribution. But if the Polish regional economies are to be renewed, big innovations are precisely what are needed.

Keywords: EU integration, structural funds, Ireland, Poland, regional growth strategies 